\title{
FAKTOR PEMICU GANTUNG DIRI DI WILAYAH PANEKAN
}

\author{
Rosa De Lima Renita Sanyasi \\ Dokter Internship Puskesmas Panekan, Magetan, Jawa Timur \\ Dokter Internship RSAU dr.Efram Harsana, Magetan, Jawa Timur
}

Korespondensi: rosasanyasi@gmail.com

\begin{abstract}
ABSTRAK
Bunuh diri adalah suatu tindakan yang disengaja untuk mengakhiri hidup diri sendiri. Tindakan bunuh diri dipicu oleh berbagai faktor. Sangat sedikit literatur yang membahas kasus bunuh diri di Indonesia, terlebih faktor yang memicu gantung diri. Tujuan dari penelitian ini adalah untuk mengetahui berbagai faktor yang memicu gantung diri di wilayah Panekan, Magetan, Jawa Timur. Penelitian ini menggunakan metode penelitian case series. Terdapat 7 subjek yang terlibat dalam penelitian ini. Informasi mengenai subjek penelitian diperoleh melalui wawancara terstruktur dengan responden penelitian. Subjek penelitian didominasi oleh jenis kelamin laki-laki (57.14\%), berusia $\geq 50$ tahun (85.71\%), berpendidikan rendah (100\%), bekerja sebagai petani $(85.71 \%)$, dan menikah (100\%). Terdapat 4 pemicu utama yang teridentifikasi dalam penelitian ini, yaitu: masalah sosial, masalah ekonomi, penyakit kronik, dan adanya gangguan mental yang lama tidak tertangani. Satu subjek tidak dapat diidentifikasi pemicu utamanya, tetapi terdapat kepercayaan masyarakat setempat yang diyakini memengaruhi tindakan bunuh diri subjek tersebut. Enam subjek menunjukkan gejala gangguan mental sebelum kejadian gantung diri: 3 diantaranya (42.86\%) menunjukkan gejala skizofrenia, sedangkan 3 sisanya $(42.86 \%)$ menunjukkan gejala depresi. Tidak dijumpai riwayat gangguan mental pada keluarga subjek (100\%). Sebagian besar subjek tidak memiliki riwayat penyakit sebelumnya maupun riwayat penyakit lain pada keluarga $(85.71 \%)$. Sebagian besar subjek tidak pernah mengonsumsi NAPZA (57.14\%). Dari sisi keagamaan, sebagian besar subjek menjalankan ibadah dengan taat $(85.17 \%)$. Tidak ada subjek yang terlibat dengan hukum, militer, maupun tindak kriminal (100\%). Dalam kehidupan sosial, sebagian besar subjek memiliki hubungan yang baik dengan lingkungannya dan memiliki kepribadian ekstrovert (57.14\%). Pemicu tindakan gantung diri di wilayah Panekan antara lain masalah sosial, masalah ekonomi, penyakit kronik, dan adanya gangguan mental yang tidak tertangani.
\end{abstract}

Kata kunci: bunuh diri, gantung diri, Indonesia, faktor pemicu 


\title{
TRIGERRING FACTORS OF SUICIDE BY HANGING IN PANEKAN REGION
}

\author{
Rosa De Lima Renita Sanyasi \\ Internship Doctor at Panekan Public Health Care, Magetan, East Java \\ Internship Doctor at dr.Efram Harsana Air Force Hospital, Magetan, East Java
}

Correspondence: rosasanyasi@gmail.com

\begin{abstract}
Suicide is an intentionally act to causing own death. Triggering factors of suicide are multifactorial. There are only few literature about suicide in Indonesia, especially triggering factor of suicide by hanging.This study aimed to identify various triggering factors of suicide by hanging in Panekan Region, Magetan, East Java. This study was a descriptive study. There are 7 subjects in this study. Information of subject gained from respondent by in-depth interview. Subjects dominated by male (57.14\%), $\geq 50$ years old (85.71\%), has a low education (100\%), work as a farmer (85.71\%), and married (100\%).There were 4 identified trigerring factors: social problem, financial problem, chronic illness, and pyshiatric disorder. One subject failed to be identified a logic triggering factor, but the family has a superstition about subject's suicidal. Six subjects showed psychiatric symptoms: 3 subjects (42.86\%) showed scizophrenia symptoms and 3 subjects (42.86\%) showed depression symptoms. There were no history of psychiatric disorder in their family (100\%). Most of subjects didn't have other physical illness (85.71\%). Most of subjects didn't have a history of alcohol abuse, drug abuse, smoking, or other addictive subtances (57.14\%). From the religious aspect, most of the subjects were an obedient religionist (85.17\%). None of subjects had any criminal or military tract record (100\%). Most of subjects had a good social life and had an extrovert personality (57.14\%). Triggering factors of suicide by hanging in Panekan Region are social conflict, family conflict, chronic illness, spouse's illness, untreated psychiatric disorder, and financial problem. Superstision still has a role in some part of Panekan Region.
\end{abstract}

Keywords: suicide, hanging, Indonesia, triggering factors 


\section{PENDAHULUAN}

Bunuh diri adalah suatu tindakan yang disengaja untuk mengakhiri hidup diri sendiri. ${ }^{1}$ Pada tahun 2012, terdapat sekitar 804.000 kematian akibat bunuh diri, Asia Tenggara menyumbang $25.9 \%$ dari total kematian akibat bunuh diri di dunia. ${ }^{2}$ Bunuh diri diperkirakan akan menyumbang beban penyakit dunia sebanyak lebih dari $2 \%$ pada tahun 2020.3

Pada tahun 2006, terdapat sekitar 100.000 orang di Jakarta yang melakukan bunuh diri. ${ }^{4}$ Di Indonesia, kematian akibat bunuh diri mencapai 3.7 per 100.000 orang pada tahun 2012.5 Banyaknya kasus bunuh diri merupakan suatu indikator derajat kesehatan mental dan lingkungan sosial dari suatu negara. ${ }^{6}$

Tindakan bunuh diri dipicu oleh berbagai faktor dan bukan merupakan dampak dari satu stressor. ${ }^{7}$ Bunuh diri timbul karena interaksi dari berbagai faktor, seperti faktor sosial, faktor psikologis, faktor kultural, faktor ekonomi, dan faktor biologis. Stigma yang buruk mengenai gangguan mental dan bunuh diri mengakibatkan kasus bunuh diri banyak yang tidak terlaporkan. ${ }^{8}$

Gantung diri merupakan metode bunuh diri yang paling sering digunakan di berbagai negara. ${ }^{9}$ Gantung diri merupakan jeratan pada leher akibat gaya gravitasi dari berat badan korban sendiri.10 Kematian akibat gantung diri timbul akibat adanya himpitan mekanik di leher yang memicu asfiksia dan oklusi pembuluh darah, fraktur vertebra cervicalis, serta cedera medula spinalis. ${ }^{11}$ Indonesia tidak memiliki data nasional mengenai insidensi dan prevalensi bunuh diri khususnya gantung diri. ${ }^{4}$ Sangat sedikit literatur yang membahas kasus bunuh diri di Indonesia, terlebih faktor pemicu yang memicu gantung diri. ${ }^{12}$

\section{TUJUAN}

Tujuan dari penelitian ini adalah untuk mengukur berbagai faktor yang memicu tindakan gantung diri di wilayah Panekan, Magetan, Jawa Timur.

\section{METODE}

Penelitian ini menggunakan metode penelitian case series. Pengumpulan data dilakukan pada tanggal 4 Maret 2017 sampai 26 Maret 2017 di wilayah cakupan Puskesmas Panekan, Magetan, Jawa Timur. Subjek penelitian merupakan pelaku gantung diri di wilayah Panekan, Magetan, Jawa Timur, yang tercatat dalam data Polsek Panekan. Responden penelitian merupakan kerabat subjek penelitian. Kerabat subjek penelitian merupakan setiap orang yang masuk dalam genogram atau pohon keluarga subjek penelitian, yang mengenal pribadi subjek, dan mengetahui kehidupan subjek sehari-hari. Pengumpulan data dilakukan melalui wawancara terstruktur pada responden penelitian yang telah menandatangani lembar persetujuan.

Proses perizinan untuk melakukan penelitian diberikan oleh Kepala Puskesmas Panekan. Data subjek penelitian diperoleh secara resmi dari Polsek Panekan dengan total terdapat 10 data subjek penelitian. Kriteria inklusi subjek penelitian meliputi: (i) gantung diri terjadi pada rentang tahun 2010 sampai 2017, (ii) identitas dan alamat subjek tercantum jelas, (iii) tanggal kejadian gantung diri tercantum jelas. Kriteria eksklusi subjek penelitian meliputi: (i) subjek penelitian merupakan anggota keluarga atau merupakan pejabat pemerintahan, tentara, kepolisian, atau tokoh publik dan (ii) responden penelitian menolak untuk di- 
wawancarai. Sebelum melakukan wawancara terstruktur pada responden penelitian, perizinan juga dilakukan pada perangkat desa setempat, dimana responden berdomisili.

Data subjek penelitian yang dikumpulkan meliputi: (i) jenis kelamin; (ii) usia; (iii) pendidikan terakhir; (iv) pekerjaan; (v) tanggal kematian; (vi) status marital dan perceraian; (vii) jumlah anak; (viii) perkiraan pemicu utama gantung diri; (ix) gejala gangguan mental sebelumnya; (x) riwayat penyakit sebelumnya; (xi) riwayat gangguan mental keluarga; (xii) riwayat penyakit keluarga; (xiii) riwayat konsumsi NAPZA; (xiv) riwayat keagamaan; (xv) riwayat keterlibatan hukum, militer, atau tindak pidana; (xvi) riwayat aktivitas sosial; dan (xvii) riwayat kepribadian. Pendidikan digolongkan sebagai pendidikan rendah apabila tidak menamatkan wajib belajar 9 tahun. Kepribadian dibedakan menjadi dua, yaitu ekstrovert dan introvert. Data responden penelitian yang dikumpulkan meliputi: (i) jenis kelamin; (ii) usia; (iii) pendidikan terakhir; (iv) pekerjaan; (v) status marital; (vi) hubungan dengan subjek penelitian. Proses wawancara terstruktur dan pengumpulan data tersebut didampingi oleh petugas Puskesmas Panekan. Setiap data yang diperoleh dari Polsek Panekan maupun dari responden dijaga kerahasiaannya dan hanya dipergunakan untuk kepentingan penelitian ini.

\section{HASIL}

Total terdapat 10 data subjek yang diperoleh, tetapi hanya tersisa 7 data subjek yang memenuhi kriteria. Dua subjek dieksklusikan karena merupakan anggota keluarga dari pejabat pemerintahan dan tentara. Satu subjek dieksklusikan karena responden menolak untuk dilakukan wawancara terstruktur lebih lanjut. Karakteristik subjekdan responden penelitian disajikan dalam tabel 1 dan 2.

Tabel 1. Karakteristik Dasar Subjek dan Responden Penelitian Lk: Laki-laki, Pr: Perempuan, SD: Sekolah Dasar,TL: Tidak Lulus, SMA: Sekolah Menengah Atas

\begin{tabular}{|c|c|c|c|c|c|c|c|c|}
\hline & $\begin{array}{l}0 \\
\substack{0 \\
0} \\
1\end{array}$ & 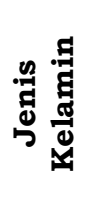 & 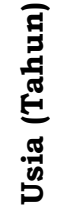 & 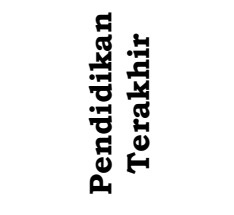 & 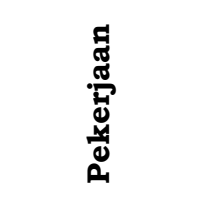 & 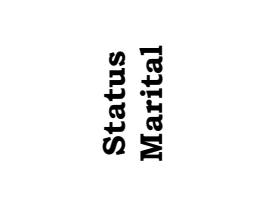 & 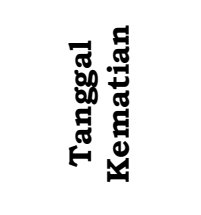 & 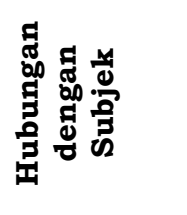 \\
\hline \multirow{7}{*}{$\frac{\sqrt{0}}{\frac{0}{0}}$} & 1 & $\mathrm{Lk}$ & 60 & $\mathrm{SD}$ & Petani & Menikah & $7 / 3 / 2011$ & - \\
\hline & 2 & $\mathrm{Pr}$ & 56 & $\mathrm{SD}(\mathrm{TL})$ & Petani & Menikah & $28 / 4 / 2012$ & - \\
\hline & 3 & $\operatorname{Pr}$ & 50 & SD (TL) & Petani & Menikah & $23 / 3 / 2013$ & - \\
\hline & 4 & $\mathrm{Lk}$ & 75 & $\mathrm{SD}(\mathrm{TL})$ & Wiraswasta & Menikah, istri 2 & $25 / 7 / 2015$ & - \\
\hline & 5 & $\mathrm{Pr}$ & 70 & $\mathrm{SD}(\mathrm{TL})$ & Petani & Menikah & $31 / 8 / 2015$ & - \\
\hline & 6 & Lk & 65 & $\mathrm{SD}$ & Petani & Menikah & $17 / 8 / 2016$ & - \\
\hline & 7 & $\mathrm{Lk}$ & 43 & $\mathrm{SD}(\mathrm{TL})$ & Petani & Menikah & $16 / 1 / 2017$ & - \\
\hline \multirow{7}{*}{ 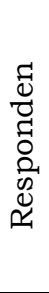 } & 1 & Lk & 42 & SMA & Wiraswasta & Menikah & - & $\begin{array}{c}\text { Anak } \\
\text { Kandung }\end{array}$ \\
\hline & 2 & $\mathrm{Lk}$ & 74 & $\mathrm{SD}(\mathrm{TL})$ & Petani & Menikah & - & Suami \\
\hline & 3 & $\mathrm{Lk}$ & 55 & $\mathrm{SD}(\mathrm{TL})$ & Petani & Menikah & - & Suami \\
\hline & 4 & $\mathrm{Lk}$ & 61 & SMA & Petani & Menikah & - & Menantu \\
\hline & 5 & $\operatorname{Pr}$ & 55 & $\mathrm{SD}(\mathrm{TL})$ & Petani & Menikah & - & Tante \\
\hline & 6 & $\operatorname{Pr}$ & 60 & Tidak sekolah & Petani & Menikah & - & Istri \\
\hline & 7 & Lk & 58 & SD (TL) & Petani & Menikah & - & Kakak Ipar \\
\hline
\end{tabular}


Subjek dan responden penelitian didominasi oleh jenis kelamin laki-laki (57.14\% ; 71.43\%), berusia $\geq 50$ tahun $(85.71 \% ; 85.71 \%)$, berpendidikan rendah $(100 \%$; $85.71 \%$ ), dan bekerja sebagai petani
(85.71\% ; 85.71\%). Semua subjek penelitian menikah dan tidak ada yang mengalami perceraian $(100 \%)$. Responden penelitian yang terlibat semuanya memiliki hubungan yang erat dengan subjek penelitian.

Tabel 2. Persentase Karakteristik Dasar Subjek dan Responden Penelitian

\begin{tabular}{llcccc}
\hline \multirow{2}{*}{ Karakteristik } & \multicolumn{1}{c}{ Subjek } & \multicolumn{4}{c}{ Responden } \\
\cline { 3 - 6 } Jenis & Laki-laki & 4 & $57.14 \%$ & 5 & $71.43 \%$ \\
Kelamin & Perempuan & 3 & $42.86 \%$ & 2 & $28.57 \%$ \\
Usia & $\geq 50$ tahun & 6 & $85.71 \%$ & 6 & $85.71 \%$ \\
\multirow{3}{*}{ Pendidikan } & S 50 tahun & 1 & $14.29 \%$ & 1 & $14.29 \%$ \\
& Tidak & 0 & $0 \%$ & 1 & $14.29 \%$ \\
& sekolah & 5 & $71.43 \%$ & 4 & $57.14 \%$ \\
& SD (TL) & 2 & $28.57 \%$ & 0 & $0 \%$ \\
\multirow{5}{*}{ Pekerjaan } & SD & 0 & $0 \%$ & 2 & $28.57 \%$ \\
\multirow{2}{*}{ Status } & SMA & & & & \\
Marital & Petani & 6 & $85.71 \%$ & 6 & $85.71 \%$ \\
& Wiraswasta & 1 & $14.29 \%$ & 1 & $14.29 \%$ \\
& Menikah & 7 & $100 \%$ & 7 & $100 \%$ \\
\hline
\end{tabular}

SD: Sekolah Dasar,TL: Tidak Lulus, SMA: Sekolah Menengah Atas

Penggalian informasi pada responden 1 tidak dapat ditemukan alasan logis pemicu tindakan gantung diri dari subjek 1. Tidak diperoleh informasi adanya gejala gangguan mental, penyakit fisik, masalah sosial, masalah ekonomi, maupun masalah hukum yang dapat memicu tindakan gantung diri. Responden 1 menyatakan adanya kepercayaan masyarakat setempat yang diyakini memicu tindakan gantung diri dari subjek 1. Mereka percaya bahwa lunturnya kebudayaan dan hilangnya salah satu tradisi di daerah tersebut membuat lingkungan desa tersebut menjadi tidak baik dan memicu banyaknya tindakan bunuh diri di lingkungan tersebut.

Responden 2 menyatakan pemicu utama tindakan gantung diri dari subjek 2 adalah adanya konflik dengan aparat pemerintahan terkait pembangunan rumahnya. Sebelum melakukan gantung diri, subjek 2 menunjukkan gejala gangguan mental berupa sering berdiam diri, berteriak tanpa sebab yang jelas, dan kebingungan. Hasil wawancara terstruktur dengan responden 3 dapat disimpulkan pemicu utama tindakan gantung diri dari subjek 3 adalah penyakit diabetes mellitus yang telah diderita subjek selama 7 tahun dengan komplikasi gagal ginjal, sehingga subjek memerlukan hemodialisa 2 kali per minggu. Penyakit kronik tersebut juga membuat subjek 3 mengalami kesulitan ekonomi. Sebelum melakukan gantung diri, subjek 3 menunjukkan gejala gangguan mental berupa mudah sedih dan menjadi malas dibanding sebelumnya.

Pemicu utama tindakan gantung diri dari subjek 4 adalah adanya konflik keluarga, yaitu dengan anak subjek. Subjek 4 juga mengalami permasalahan ekonomi yaitu terjerat hutang dengan suatu 
bank yang mengakibatkan harta bendanya disegel. Subjek 4 pernah melakukan percobaan gantung diri sebelumnya. Hasil wawancara terstruktur dengan responden 5 dapat disimpulkan pemicu utama tindakan gantung diri dari subjek 5 adalah kesepian dan kehidupan yang terisolasi. Subjek 5 selalu hidup seorang diri. Suami subjek meninggal 2 tahun sebelum kejadian gantung diri, kedua anaknya pergi merantau selama bertahun-tahun dan tidak pernah berkunjung. Sebelum melakukan gantung diri, subjek menunjukkan gejala gangguan mental berupa sering berdiam diri dan berjalan tanpa arah tujuan.

Pemicu utama tindakan gantung diri dari subjek 6 adalah gangguan mental yang lama tidak tertangani dengan baik. Subjek 6 sering menyendiri, kebingungan, pelupa, sulit tidur, dan sulit diajak berkomunikasi. Subjek 6 pernah melakukan percobaan gantung diri sebelumnya. Hasil wawancara terstruktur dengan responden 7, dapat disimpulkan pemicu utama tindakan gantung diri dari subjek 7 adalah istri subjek yang mengalami penyakit kanker stadium akhir dan mengalami permasalahan ekonomi karena biaya pengobatan istri. Sebelum melakukan gantung diri, subjek menunjukkan gejala gangguan mental berupa wajah tampak murung, tatapan kosong, dan tampak kebingungan. Hasil wawancara terstruktur tampak pada tabel 3.

Tabel 3. Hasil Wawancara terstruktur

\begin{tabular}{|c|c|c|c|c|c|c|c|}
\hline Data & Subjek 1 & Subjek 2 & Subjek 3 & Subjek 4 & Subjek 5 & Subjek 6 & Subjek 7 \\
\hline $\begin{array}{l}\text { Pemicu } \\
\text { Utama }\end{array}$ & $\begin{array}{l}\text { Tidak } \\
\text { diketahui } \\
\text { (kepercay } \\
\text { aan } \\
\text { masyarak } \\
\text { at } \\
\text { setempat) }\end{array}$ & $\begin{array}{l}\text { Masalah } \\
\text { sosial }\end{array}$ & $\begin{array}{l}\text { Penyakit } \\
\text { kronik dan } \\
\text { masalah } \\
\text { ekonomi }\end{array}$ & $\begin{array}{l}\text { Masalah } \\
\text { sosial dan } \\
\text { masalah } \\
\text { ekonomi }\end{array}$ & $\begin{array}{l}\text { Masalah } \\
\text { sosial }\end{array}$ & $\begin{array}{l}\text { Gangguan } \\
\text { mental } \\
\text { yang lama } \\
\text { tidak } \\
\text { tertangani }\end{array}$ & $\begin{array}{l}\text { Penyakit } \\
\text { kronik } \\
\text { (pada } \\
\text { pasangan } \\
\text { ) dan } \\
\text { masalah } \\
\text { ekonomi }\end{array}$ \\
\hline $\begin{array}{l}\text { Riwayat } \\
\text { Gejala } \\
\text { Gangguan } \\
\text { Mental } \\
\text { Riwayat }\end{array}$ & Tidak ada & Ada & Ada & Ada & Ada & Ada & Ada \\
\hline $\begin{array}{l}\text { Giwayat } \\
\text { Mengguan } \\
\text { Kental } \\
\text { Keluarga }\end{array}$ & Tidak ada & Tidak ada & Tidak ada & Tidak ada & Tidak ada & Tidak ada & $\begin{array}{l}\text { Tidak } \\
\text { ada }\end{array}$ \\
\hline $\mathrm{RPD}$ & Tidak ada & Tidak ada & $\begin{array}{l}\text { DM, gagal } \\
\text { ginjal }\end{array}$ & Tidak ada & Tidak ada & Tidak ada & $\begin{array}{l}\text { Tidak } \\
\text { ada }\end{array}$ \\
\hline RPK & Tidak ada & Tidak ada & $\begin{array}{l}\text { Saudara } \\
\text { kandung, } \\
\text { DM }\end{array}$ & Tidak ada & Tidak ada & Tidak ada & $\begin{array}{l}\text { Tidak } \\
\text { ada }\end{array}$ \\
\hline $\begin{array}{l}\text { Riwayat } \\
\text { Konsumsi } \\
\text { NAPZA }\end{array}$ & $\begin{array}{l}\text { Rokok, } \pm 3 \\
\text { batang/ } \\
\text { hari }\end{array}$ & Tidak ada & Tidak ada & $\begin{array}{l}\text { Merokok } \\
<1 \\
\text { bungkus / } \\
\text { hari }\end{array}$ & Tidak ada & Tidak ada & $\begin{array}{l}\text { Merokok } \\
<1 \\
\text { bungkus } \\
\text { / hari }\end{array}$ \\
\hline $\begin{array}{l}\text { Riwayat } \\
\text { Keagamaan }\end{array}$ & $\begin{array}{l}\text { Taat } \\
\text { beribadah }\end{array}$ & $\begin{array}{l}\text { Taat } \\
\text { beribadah }\end{array}$ & $\begin{array}{l}\text { Taat } \\
\text { beribadah }\end{array}$ & $\begin{array}{l}\text { Tidak taat } \\
\text { beribadah }\end{array}$ & $\begin{array}{l}\text { Taat } \\
\text { beribadah }\end{array}$ & $\begin{array}{l}\text { Taat } \\
\text { beribadah }\end{array}$ & $\begin{array}{l}\text { Taat } \\
\text { beribada } \\
\mathrm{h}\end{array}$ \\
\hline $\begin{array}{l}\text { Perceraian / } \\
\text { Riwayat } \\
\text { Pernikahan }\end{array}$ & $\begin{array}{l}\text { Menikah } 1 \\
\text { kali, } 5 \\
\text { anak }\end{array}$ & $\begin{array}{l}\text { Menikah } 1 \\
\text { kali, tidak } \\
\text { memiliki } \\
\text { anak } \\
\text { kandung, } \\
\text { memiliki } 1 \\
\text { anak } \\
\text { angkat }\end{array}$ & $\begin{array}{l}\text { Menikah } 1 \\
\text { kali, } 3 \\
\text { anak }\end{array}$ & $\begin{array}{l}\text { Menikah } 2 \\
\text { kali, } 4 \\
\text { anak } \\
\text { dengan } \\
\text { istri } \\
\text { pertama, } 3 \\
\text { anak } \\
\text { dengan } \\
\text { istri kedua }\end{array}$ & $\begin{array}{l}\text { Menikah } 1 \\
\text { kali, } 2 \\
\text { anak, } \\
\text { suami } \\
\text { pernah } \\
\text { menikah } 4 \\
\text { kali } \\
\text { sebelumn } \\
\text { va }\end{array}$ & $\begin{array}{l}\text { Menikah } 1 \\
\text { kali, } 1 \\
\text { anak }\end{array}$ & $\begin{array}{l}\text { Menikah } \\
1 \text { kali, } 1 \\
\text { anak }\end{array}$ \\
\hline
\end{tabular}




\begin{tabular}{|c|c|c|c|c|c|c|c|}
\hline Data & Subjek 1 & Subjek 2 & Subjek 3 & Subjek 4 & Subjek 5 & Subjek 6 & Subjek 7 \\
\hline $\begin{array}{l}\text { Keterlibatan } \\
\text { Hukum/Milit } \\
\text { er/Kriminal }\end{array}$ & Tidak ada & Tidak ada & Tidak ada & Tidak ada & Tidak ada & Tidak ada & $\begin{array}{l}\text { Tidak } \\
\text { ada }\end{array}$ \\
\hline $\begin{array}{l}\text { Riwayat } \\
\text { Aktivitas } \\
\text { Sosial }\end{array}$ & Aktif & Aktif & Aktif & Tidak aktif & Tidak aktif & Aktif & $\begin{array}{l}\text { Tidak } \\
\text { aktif }\end{array}$ \\
\hline $\begin{array}{l}\text { Riwayat } \\
\text { Kepribadian }\end{array}$ & Ekstrovert & Ekstrovert & Ekstrovert & Introvert & Introvert & Ekstrovert & Introvert \\
\hline
\end{tabular}

Terdapat 4 pemicu utama yang teridentifikasi dalam penelitian ini, yaitu: masalah sosial, masalah ekonomi, penyakit kronik, dan adanya gangguan mental yang lama tidak tertangani. Terdapat satu subjek yang tidak teridentifikasi pemicu utamanya. Enam subjek menunjukkan gejala gangguan mental sebelum kejadian gantung diri: 3 diantaranya (42.86\%) menunjukkan gejala skizofrenia, yaitu subjek 2,5, dan 6 , sedangkan 3 sisanya (42.86\%) menunjukkan gejala depresi, yaitu subjek 3,4, dan 7. Tidak dijumpai riwayat gangguan mental pada keluarga semua subjek
(100\%). Sebagian besar subjek tidak memiliki riwayat penyakit sebelumnya maupun riwayat penyakit lain pada keluarga (85.71\%). Sebagian besar subjek tidak pernah mengonsumsi NAPZA (57.14\%). Dari sisi keagamaan, sebagian besar subjek menjalankan ibadah dengan taat $(85.17 \%)$. Tidak ada subjek yang terlibat dengan hukum, militer, maupun tindak kriminal (100\%). Dalam kehidupan sosial, sebagian besar subjek memiliki hubungan yang baik dengan lingkungannya dan memiliki kepribadian ekstrovert (57.14\%).

Tabel 4. Persentase Hasil Wawancara Terstruktur

\begin{tabular}{llcc}
\hline & Data & Jumlah & Persentase \\
\hline & Masalah sosial & 3 & $30 \%$ \\
& Masalah ekonomi & 3 & $30 \%$ \\
Pemicu Utama & Penyakit kronik & 2 & $20 \%$ \\
& Gangguan mental yang & 1 & $10 \%$ \\
& lama tidak tertangani & & \\
& Tidak diketahui & 1 & $10 \%$ \\
Gejala Gangguan Mental & Ada: Skizofrenia & 3 & $42.86 \%$ \\
& Depresi & 3 & $42.86 \%$ \\
Riwayat Gangguan Mental & Tidak Ada & 1 & $14.29 \%$ \\
Keluarga & Tidak Ada & 7 & $100 \%$ \\
RPD & Ada & 1 & $14.29 \%$ \\
RPK & Tidak Ada & 6 & $85.71 \%$ \\
Riwayat Konsumsi NAPZA & Ada & 1 & $14.29 \%$ \\
Riwayat Keagamaan & Tidak Ada & 6 & $85.71 \%$ \\
Riwayat Pernikahan & Tida: Rokok & 3 & $42.86 \%$ \\
Riwayat Perceraian & Taat & 4 & $57.14 \%$ \\
Riwayat Keterlibatan & Tidak Taat & 6 & $85.71 \%$ \\
Hukum/Militer/Kriminal & Menikah & 7 & $14.29 \%$ \\
Riwayat Aktivitas Sosial & Tidak Ada & 7 & $100 \%$ \\
& Tidak Ada & 7 & $100 \%$ \\
& Aktif & 4 & $100 \%$
\end{tabular}




\begin{tabular}{|c|c|c|c|}
\hline & Data & Jumlah & Persentase \\
\hline \multirow{3}{*}{ Riwayat Kepribadian } & Tidak aktif & 3 & $42.86 \%$ \\
\hline & Ekstrovert & 4 & $57.14 \%$ \\
\hline & Introvert & 3 & $42.86 \%$ \\
\hline
\end{tabular}

RPD: Riwayat Penyakit Dahulu; RPK: Riwayat Penyakit Keluarga; NAPZA: Narkotika, Psikotropika, dan Zat Aditif

\section{DISKUSI}

Subjek penelitian didominasi oleh jenis kelamin laki-laki (57.14\%). Hasil ini selaras dengan berbagai penelitian terdahulu.13,14 Penelitian oleh Vijayakumari (2011) pada 65 kasus gantung diri menunjukkan $52.3 \%$ dari pelaku gantung diri adalah laki-laki. ${ }^{15}$ Penelitian oleh Pal, et al. (2016) menyatakan rasio gantung diri pada laki-laki dan perempuan adalah $2: 1$, bahkan menurut penelitian oleh Der, et al. rasio tersebut dapat mencapai $7: 1.16,17 \mathrm{Hal}$ ini diperkirakan karena laki-laki memiliki aktivitas yang lebih tinggi dan lebih rentan terhadap stressor. 18

Sebagian besar subjek
penelitian berusia $\geq 50$ tahun (85.71\%). Hal ini sejalan dengan penelitian oleh Tewksburya, et al. (2010) yang menyatakan kejadian bunuh diri paling sering terjadi pada usia $>75$ tahun $(16,9$ per 100.000$)$ dan usia 45-54 tahun $(16,5$ per 100.000). ${ }^{19}$ Kejadian bunuh diri 67 kali lipat lebih tinggi pada usia lanjut daripada populasi umum. ${ }^{14}$ Penyebab utama para usia lanjut melakukan bunuh diri adalah adanya penyakit fisik. Selain itu terdapat trias "3D" yang menyebabkan pemicu bunuh diri pada usia lanjut lebih tinggi, yaitu depresi, demensia ringan, dan delirium. 20

Gangguan mental memegang peranan dalam memicu bunuh diri'21. Hal tersebut terbukti dalam penelitian ini. Sebelum bunuh diri, tiga subjek pada penelitian ini $(42.86 \%)$ menunjukkan gejala skizofrenia, seperti sedangkan 3 sisanya (42.86\%) menunjukkan gejala depresi. Bunuh diri sering terkait dengan gangguan mental seperti depresi, skizophrenia, gangguan bipolar. ${ }^{1}$ Penelitian Masangoet al. (2008) menyatakan depresi adalah gangguan jiwa yang paling sering terkait dengan tindakan bunuh diri. ${ }^{22}$ Sekitar 400 per 100.000 pasien depresilaki-laki dan 180 per 100.000 pasien depresi perempuan, melakukan bunuh diri. ${ }^{22}$ Penelitian lain pada 128 kasus gantung diri menunjukkan sebanyak 17 kasus (13.3\%) mengalami skizophrenia. ${ }^{23}$

Pada penelitian ini terdapat 2 subjek yang pernah melakukan percobaan gantung diri sebelumnya, yaitu subjek 4 dan 6 . Hal ini sesuai dengan penelitian Kosky et al. yang menyatakan bahwa $14.6 \%$ dari sampel penelitian pernah melakukan percobaan bunuh diri sebelumnya. ${ }^{24}$ Seseorang yang pernah melakukan percobaan bunuh diri dengan gantung diri memiliki peluang yang besar untuk berhasil melakukan bunuh diri dikemudian hari.25 Menurut Masango et al. (2008) 50\% orang yang meninggal karena bunuh diri, setidaknya pernah melakukan percobaan bunuh diri sebelumnya minimal 1 kali. ${ }^{22}$

Masalah ekonomi banyak berperan dalam memicu bunuh diri pada penelitian ini $(30 \%)$. Penelitian Chandegara, et al. (2014) di India menyimpulkan kasus gantung diri tinggi pada kelompok subjek dengan tingkat ekonomi rendah.18 Faktor finansial memegang peranan sebesar $7.7 \%$ dalam kejadian gantung diri. 15 Masalah finansial sebagai pemicu bunuh diri lebih sering terjadi di Asia daripada di negara barat. ${ }^{12}$ 
Masalah sosial memegang peranan sebanyak 30\% dalam penelitian ini. Masalah sosial tersebut meliputi konflik dengan keluarga, konflik dengan aparat pemerintahan, dan kehidupan yang terisolasi. Konflik keluarga, kemampuan bersosialisasi yang rendah, kehidupan yang terisolasi berkontribusi pada tindakan bunuh diri pada dewasa. ${ }^{26}$ Menurut Mars, et al. (2014) permasalahan sosial dan interpersonal memegang peranan dalam memicu bunuh diri. ${ }^{21}$ Penelitian oleh Pal, et al. (2016) pada 122 kasus bunuh diri di India menyatakan bahwa konflik keluarga berkontribusi sebesar $6.55 \%$ sebagai salah satu faktor pemicu gantung diri, sedangkan pada penelitian Alimohammadi, et al. (2013) sebesar 8.5\%. ${ }^{1,16}$

Penyakit kronik juga menjadi salah satu pemicu bunuh diri dalam tindakan ini (20\%), yaitu pada subjek 3 dan 7. Penyakit kronik tersebut dialami oleh subjek penelitian itu sendiri (subjek 3) dan dialami oleh pasangan hidup subjek penelitian (subjek 7). Nyeri kronik maupun penyakit kronik diketahui dapat menjadi salah satu pemicu bunuh diri. $15,20,22$

Satu subjek penelitian, yaitu subjek 1, tidak dapat diidentifikasi pemicu utama bunuh diri, tetapi terdapat kepercayaan masyarakat setempat yang diyakini memicu tindakan bunuh diri subjek tersebut. Hal ini menjadi tantangan untuk dilakukan penelitian lebih lanjut untuk mengetahui kaitan kepercayaan masyarakat dengan tindakan bunuh diri atau terdapat suatu faktor pemicu lain yang belum terdeteksi. Superstiton memiliki korelasi dengan kecenderungan untuk bunuh diri di suatu wilayah. ${ }^{27}$ Perbedaan kebudayaan di setiap daerah berdampak pada perbedaan kejadian bunuh diri di setiap daerah tersebut. Cultural-bound syndromes merupakan salah satu contoh perilaku yang menyimpang pada suatu daerah yang dapat memengaruhi perilaku bunuh diri. ${ }^{28}$

\section{KESIMPULAN}

Faktor pemicu gantung diri yang teridentifikasi pada penelitian ini adalah masalah sosial, masalah ekonomi, penyakit kronik, dan adanya gangguan mental yang tidak tertangani.

\section{DAFTAR PUSTAKA}

1. Alimohammadi AM, Mehrpisheh $\mathrm{SH}$, Memarian A. Epidemiology of cases of suicide due to hanging who referred to forensic center of shahriar in 2011. Int Jour Med Tox For Med. 2013;3(4):121-125.

2. World Health Organization. Preventing suicide: a global imperative. Switzerland: WHO Document Production Services. 2014.

3. World Health Organization. Public health action for the prevention of suicide: a framework. Switzerland: WHO Document Production Services. 2012.

4. Wirasto RT. Suicide prevention in Indonesia: providing public advocacy. JMAJ. 2012;55(1):98104.

5. World Health Organization. World health statistics 2016: monitoring health for the sdgs, sustainable development goals. Switzerland: WHO Document Production Services. 2016

6. Shiuli R, Abhishek P, Anoop KV, Mousami S. Frequency of hanging deaths in Lucknow, India 20082012. Int Jour Med Tox For Med. 2015;5(3):126-130. 
7. Der EM, Dakwah IA, DerkyiKwarteng L, Badu AA. Hanging as a method of suicide in Ghana: a 10 year autopsy study. Pathol Discov. 2016;4(2).

8. World Health Organization. Preventing suicide, a community engagement toolkit, pilot version 1.0. Switzerland: WHO Document Production Services. 2016.

9. Ajdacic-Gross V, Weiss MG, Ring M,Hepp U, Bopp M, Gutzwiller F, Rössler W. methods of suicide: international suicide patterns derived from the who mortality database. Bulletin of the WHO. 2008;86(9):726-732.

10. Sauvageau A. About strangulation and hanging: language matters. $J$ Emerg Trauma Shock. 2011;4(2):320.

11. Gunnell D, Bennewith O, Hawton K, Simkin S, Kapur N. The epidemiology and prevention of suicide by hanging: a systematic review. Int Journal of Epid. 2005;34:433-442.

12. Chen YY, Wu KCC, Yousuf S, Yip PSF. Suicide in asia: opportunities and challenges. Epidemiol Rev. 2012;34:129-144.

13. Lester D. Suicide and culture. WCPRR. 2008; 51-68.

14. Murphy E, Kapur N, Webb R. Risk factors for repetition and suicide following self-harm in older adults: multicentre cohort study. The British Journal of Psych. 2012; 200:399-404.

15. Vijayakumari N. Suicidal hanging: a prospective study. $J$ Indian Acad Forensic Med. 2011;33(4).

16. Pal SK, Sharma A, Sehgal A, Kaushik N, Rana A. Hanging suicides in himachal pradesh: an analysis of forensic cases. Int $J$ Forensic Sci Pathol. 2016;4(11):297-304.

17. Der EM, Dakwah IA, DerkyiKwarteng L, Badu AA. Hanging as a method of suicide in ghana: a 10 year autopsy study. Pathol Discov. 2016;4(2).

18. Chandegara P, Patel J, Zanzrukiya K, Patel U, Parkhe S, Gajera C, Govekar G. Sociodemographic profile of hanging cases at new civil hospital, Surat. Int Journal of Med Sci and Public Health. 2014, 3(12).

19. Tewksburya R, Suresha G, Holmesa RM. Factors related to suicide via firearms and hanging and leaving of suicide notes. Int Journal of Men's Health. 2010;9(1):40-49.

20. Takahashi Y. Depression and suicide. JMAJ. 2001; 44(8): 359363.

21. Mars B, Burrows S, Hjelmeland H, Gunnell D. Suicidal behaviour across the african continent:a review of the literature. $B M C$ Public Health. 2014;14:606.

22. Masango SM, Rataemane ST, Motojesi AA. Suicide and suicide risk factors: a literature review. SA Fam Pract. 2008;50(6):25-28.

23. Bennewith O, Gunnell D, Kapur N,Turnbull P, Simkin S, Sutton L, Hawton K. Suicide by hanging: multicentre study based on coroners' records in england. British Journal of Psychiatry. 2005;186:260-261.

24. Kosky RJ, Dundas P. Death by hanging: implications for prevention of an important method of youth suicide. Australian and New Zealand 


\section{Journal of Psychiatry. 2000;34:836-841.}

25. Runeson B, Tidemalm D, Dahlin $\mathrm{M}$,Lichtenstein $\mathrm{P}$, Langstrom $\mathrm{N}$. Method of attempted suicide as predictor of subsequent successful suicide: national long term cohort study. BMJ. 2010;340:c3222.

26. Smischney TM, Chrisler A, Villarruel FA. 2014. Research brief : risk factors for adolescent suicide. the military reach team, the research and outreach
(REACH) laboratory. The University of Minnesota: United States.

27.Zhang $\mathrm{J}, \mathrm{Xu} \mathrm{H}$. The effects of religion, superstition, and perceived gender inequality on the degree of suicide intent: a study of serious attempters in China. Omega (Westport). 2007;55(3):185-197.

28. Maharajh HD, Abdool PS. Cultural aspects of suicide. The Scientific World Journal. 2005;5:736-746. 